\title{
PERAN PEMBINAAN LITERASI TERHADAP PERUBAHAN SIKAP DAN TINGKAH LAKU NARAPIDANA DI LEMBAGA PEMASYARAKATAN KELAS IIB TUBAN
}

Hanin Kusuma Ardy

Manajemen Pemasyarakatan, Politeknik Ilmu Pemasyarakatan, haninkusuma3@gmail.com

In realizing the purpose of the correctional system, namely to make inmates become better human beings, a coaching program was formed by involving the community in the process of coaching. The number of cases of deviant behavior against the norms and rule of law that applies, occurs because of the crisis of character experienced by the people of Indonesia. Therefore, it takes real action from various elements to improve the quality of education in Indonesia, one of which is through literacy. Literacy serves to improve the understanding and delivery of information, literacy is also considered to affect the psychic in the form of attitudes or characters and behaviors of a person. This study aims to find out the cause of the selection of literacy programs as one of the coaching programs and the process to be able to play a positive role in inmates. This study uses qualitative approach with data analysis techniques in the form of triangulation of data presented descriptively. Data retrieval is done by means of observations, interviews, and previous case studies. Data in the form of primary data obtained through interviews of two officers and two inmates as well as secondary data obtained through supporting documents and previous case studies. The coaching program organized by Class IIB Tuban Prison has shown results through changes in the attitude and behavior of inmates in a environmental conduciveness in prisons.
\end{abstract}

ARTICLE INFO Keywords:

Coaching Literacy; Attitudes, Behaviors;

Inmates

\section{Cite this paper:}

Ardy, H. K. (2021). Peran

Pembinaan Literasi

Terhadap Perubahan Sikap

Dan Tingkah Laku

Narapidana Di Lembaga

Pemasyarakatan Kelas IIB

Tuban. Widya Yuridika:

Jurnal Hukum, 4(2).

\section{Scope Article}

Law and Society

\section{PENDAHULUAN}

Lembaga Pemasyarakatan Kelas IIB Tuban memiliki kapasitas penghuni sebanyak 266 orang. Saat ini, Lapas Tuban memiliki jumlah penghuni sebanyak 295 orang. Dibalik jumlah penghuni di dalam lapas yang sudah melebihi kapasitas, masih ada banyak pelaku tindak pidana dalam status tahanan tingkat penahanan dan peradilan yang ditempatkan di ruang tahanan Polres Tuban dan Polsek setempat. Hal ini bukan tidak berdasar, melainkan karena setelah muncul pandemi COVID-19 Direktorat Jenderal Pemasyarakatan memberikan perintah agar tidak menerima tahanan sebelum dalam status tahanan tingkat penuntutan (AIII). Fenomena overcapacity ini tidak lagi mengejutkan dunia pemasyarakatan, meskipun saat adanya pandemi COVID-19 telah dilaksanakan pembebasan bersyarat dan asimilasi secara besar-besaran pada tahun 2020 tidak membuat angka pelanggar tindak pidana menurun.

Melihat fenomena tersebut dapat dilihat bahwa seiring perkembangan zaman banyak terjadi perubahan dan perkembangan dalam masyarakat yang disebabkan oleh globalisasi. 
Salah satu bentuk nyata globalisasi ini adalah adanya internet yang merupakan suatu jaringan dengan kemampuan untuk mengakses berbagai macam portal pencarian bahkan portal media sosial tidak hanya di lingkup daerah tempat tinggal saja, namun juga di lingkup daerah lain di seluruh dunia melalui berita, komunikasi, video, dan lain sebagainya. Dibandingkan dengan jumlah penduduk, Indonesia merupakan negara dengan jumlah pengguna Internet yang relatif tinggi. Penduduk Indonesia saat ini berdasarkan data dari Badan Pusat Statistik adalah sebanyak 270,2 juta jiwa ([BPS] Badan Pusat Statistik, p. 3). Sedangkan menurut survei Asosiasi Penyelenggara Jasa Internet (APJII), jumlah pengguna Internet di Indonesia saat ini sebanyak 196,7 juta penduduk jiwa (APJII, 2020). Jika kedua data tersebut dibandingkan dan diprosentasekan maka akan memperoleh hasil sebesar $72,7 \%$. Angka prosentase yang cukup tinggi ini tidak selalu memberi kemanfaatan karena bergantung pada sosok penggunanya. Bagi pengguna yang bijak, internet menjadi jendela dunia yang dapat menambah wawasan mengenai perkembangan di dalam dan luar negeri Namun jika pengguna tidak bijak, maka internet dapat membawa dampak negatif, contohnya dalam hal pendidikan.

Sebagai negara yang kaya akan sumber daya alam (SDA) dan sumber daya manusia (SDM), sudah seharusnya menjadikan Indonesia sebagai negara maju. Namun faktanya hingga saat ini Indonesia masih didaulat sebagai negara berkembang. Berdasarkan pengamatan terhadap negara-negara maju dengan SDA terbatas, ditemukan bahwa dasar dari negara maju yakni adanya dukungan dari SDM yang berkualitas dengan ukuran seberapa terdidiknya SDM tersebut. Terdidiknya seseorang berarti seberapa melekatkah pendidikan pada tiap individu yang mana dapat dilihat dari cara berperilaku dan berpikir (Akbar, 2017). Pendidikan tidak melulu berbicara tentang mendapat materi dari guru di sekolah. Namun, Pendidikan juga berbicara tentang bagaimana individu memperoleh kemampuan untuk dapat istiqomah beriman terhadap Tuhan dan agamanya, menghargai sesama makhluk hidup, menyelesaikan masalah, hingga mengambil keputusan yang akan berpengaruh baik bagi diri sendiri maupun lingkungan sekitar. Maka dapat dikatakan bahwa pendidikan formal dan non formal yang berkualitas penting untuk didapat oleh tiap individu.

Pada tahun 2020, Kementerian Perencanaan Pembangunan Nasional mengungkapkan angka anak Indonesia yang putus sekolah pada tahun 2019 adalah sekitar 4,3 juta siswa, dengan faktor kualitas perkembangan emosi yang rendah. Selain karena kualitass perkembangan emosi yang rendah, putus sekolah juga disebabkan oleh beberapa hal yakni, kurang pembinaan dan pembimbingan dari orang tua, kemiskinan, demoralisasi seksual, demoralisasi yang disebabkan globalisasi, alkohol, dan kebiadaban (Purwoko, 2001, p. 22). Banyaknya kasus perilaku menyimpang terhadap norma dan aturan hukum yang berlaku terjadi karena adanya krisis karakter yang dialami oleh masyarakat Indonesia. Untuk memperbaiki fenomena tersebut, dibutuhkan aksi nyata dari berbagai elemen untuk meningkatkan kualitas pendidikan di Indonesia. Dalam mewujudkan aksi nyata tersebut membutuhkan kerjasama mulai dari pemerintah hingga sekolah (Akbar, 2017). Salah satu bentuk upaya yang dilakukan pemerintah adalah dengan mencanangkan gerakan literasi bagi masyarakat Indonesia terutama bagi pelajar. Upaya ini diperkuat dengan ditetapkannya peraturan perundang-undangan Permendikbud No. 21 Tahun 2015 tentang Penumbuhan Budi Pekerti.

Literasi dalam KBBI diartikan sebagai kemampuan menulis dan membaca, keterampilan akan sesuatu, dan kemampuan dalam mengolah informasi dan pengetahun (KBBI, 2016). Literasi juga diartikan sebagai kemampuan seseorang tidak hanya dalam membaca, menulis, mendengar, dan berlisan, namun juga dalam kecakapan lain termasuk secara digital (Anggraeni et al., 2019). Memasuki generasi 4.0, ilmu pengetahuan dengan mudah didapatkan melalui berita, artikel, jurnal, dan buku berupa elektronik yang dapat diakses kapanpun dengan mudah dan cepat. Tersedianya kemudahan mengakses ilmu pengetahuan dan informasi tidak serta merta meningkatkan minat literasi masyarakat Indonesia secara signifikan. Hal ini menjadi salah satu dari berbagai faktor penyebab banyaknya kawula muda masa depan bangsa yang terjerat kasus-kasus pidana hingga 
menyebabkan masuk ke dalam penjara. Kehidupan seseorang berubah ketika memasuki penjara karena secara tidak langsung salah satu hak asasi manusia yang dimiliki yakni kemerdekaan terenggut seperti yang tertuang dalam peraturan perundangan tentang pemasyarakatan bahwa satu-satunya hak Narapidana yakni kemerdekaan hilang. Secara otomatis pula, Narapidana menjadi tanggung jawab pemasyarakatan sehingga harus mengikuti seluruh peraturan yang ditetapkan oleh pemasyarakatan. Pemasyarakatan merupakan kegiatan pembinaan yang dilakukan oleh petugas pemasyarakatan berdasarkan sistem, kelembagaan dan tata cara pembinaan yang mana sebagai komponen terakhir sistem pidana dalam sistem peradilan pidana (UU No. 12 Tahun 1995 Tentang Pemasyarakatan, 1995).

Sebagai suatu sistem, pemasyarakatan tentunya memiliki tujuan yang ditargetkan pada warga binaan pemasyarakatan (WBP) yakni agar dapat menjadi insan manusia yang lebih bertanggung jawab, berperan dalam pembangunan nasional, sadar akan kesalahan dan berusaha untuk tidak mengulangi, serta dapat diterima oleh masyarakat ketika kembali ke dalam lingkungan masyarakat (Dwiatmodjo, 2013). Dalam memproses pelaku tindak pidana, sistem peradilan pidana yang disebut juga sebagai criminal justice system digunakan sebagai dasar pelaksanaannya yang meliputi proses penangkapan, penahanan, penuntutan, peradilan, dan pemasyarakatan. Komponen sistem yang terdiri dari beberapa instansi pemerintah memerlukan koordinasi dan upaya saling melengkapi agar sistem dapat berjalan dengan seimbang dan terintegrasi. Sistem ini memiliki empat aparat penegak hukum yang menjadi unsur komponen sistem tersebut yakni, kepolisian, kejaksaan, pengadilan, dan pemasyarakatan (Ridwan, 2016).

Dalam mewujudkan tujuan dari diberlakukannya sistem pemasyarakatan yang berasaskan reintegrasi sosial, maka pemasyarakatan melakukan bentuk pidana alternatif dengan konsep community-based corrections berupa program pembinaan kepribadian dan pembinaan kemandirian dengan melibatkan masyarakat dalam proses pembinaannya. Community-based corrections atau reintegrasi sosial memiliki tujuan agar dapat merubah perilaku narapidana sehinga dapat diterima kembali ke masyarakat dengan cara interaksi tehadap tata nilai yang berlaku di masyarakat (Hamja, 2014). Tata pelaksanaan program pembinaan dengan sasaran WBP dilaksanakan berdasar pada PP No. 31 tahun 1999 dan Kepmen Kehakiman RI No. M.02-PK.04.10 tahun 1990 dengan diiringi PP No. 32 tahun 1999 yang mengatur tentang hak-hak dan kewajiban WBP yang wajib dipenuhi oleh pemerintah dan negara ketika berada di dalam penjara.

Seperti yang telah disebutkan sebelumnya, bahwa pentingnya literasi terhadap kemampuan memahami dan menyampaikan informasi sehingga memiliki fungsi seutuhnya sebagai masyarakat memunculkan inovasi baru untuk mengadakan program pembinaan literasi di Lembaga Pemasyarakatan Kelas IIB Tuban. Selain berfungsi untuk meningkatkan pemahaman dan penyampaian informasi, literasi juga dinilai dapat mempengaruhi psikis berupa sikap atau karakter dan tingkah laku seseorang. Dengan fungsi tersebut literasi diharapkan dapat menjadi salah satu bentuk pembinaan yang benar-benar berperan dalam perbaikan sikap dan tingkah laku Narapidana melalui proses-proses yang sesuai. Penelitian ini bertujuan untuk mengetahui penyebab dipilihnya program literasi sebagai salah satu program pembinaan dan prosesnya hingga dapat berperan secara positif terhadap Narapidana.

\section{METODE}

Penelitian ini menggunakan pendekatan kualitatif dengan teknik analisis data berupa triangulasi data dan dipaparkan secara deskriptif. Data yang digunakan merupakan data primer dan sekunder. Data primer berupa hasil wawancara terhadap dua orang petugas dan dua orang Narapidana. Data sekunder berupa data pendukung seperti peraturan perundangundangan yang berkaitan dengan fokus penelitian ini, dokumen-dokumen yang menjadi obyek penelitian, serta studi kasus dari penelitian-penelitian terdahulu. Pengambilan data dilakukan dengan cara observasi, wawancara, dan studi kasus terdahulu. 


\section{HASIL DAN PEMBAHASAN}

\section{Pembinaan Literasi Narapidana}

Demi mencapai tujuan pemasyarakatan, setiap unit pelaksana teknis pemasyarakatan di Indonesia berusaha untuk menciptakan inovasi-inovasi kegiatan yang dapat mendukung pencapaian tujuan tersebut salah satunya adalah. Pembinaan merupakan bentuk aktivitas atau kegiatan yang dilaksanakan sebagai upaya peningkatan nilai kualitas terhadap ketaqwaan, intelektual, sikap, tingkah laku, dan kesehatan baik jasmani maupun rohani pada warga binaan pemasyarakatan (Peraturan Pemerintah No.31 Tentang Pembinaan Dan Pembimbingan Warga Binaan Pemasyarakatan, 1999). Pembinaan literasi tentunya memiliki karakteristik khusus yakni berhubungan dengan bahan bacaan yang mana tentunya cenderung ditempatkan dalam suatu wadah atau ruangan yang dikenal dengan sebutan perpustakaan. Penelitian mengenai pembinaan literasi terhadap narapidana sudah pernah dilakukan sebelumnya. Pada penelitian yang dilakukan oleh Karina, Mutia, dan Chamdi pada tahun 2019 mengenai peranan perpustkaan di salah satu lapas kelas I yang berada di Malang, menyatakan bahwa perpustakaan di lapas tersebut berfungsi sebagai tempat rekreasi, pusat informasi, tempat untuk melakukan pembelajaran bagi narapidana. Perpustakaan yang berperan sebagai wadah narapidana untuk meningkatkan literasi informasi sudah menampakkan hasil karya narapidana yakni berupa lukisan, buku cerita yang berisi tentang kehidupan napi di lapas (Bella et al., 2019).

Sedangkan ada pula penelitian terdahulu yang berfokus pada fungsi literasinya yakni yang dilakukan oleh Falk H. dan Martin J.P. pada tahun 2019. Penelitian ini membahas mengenai manfaat-manfaat lain yang dapat dirasakan pada setiap individu yang "melek huruf". Istilah "melek huruf" ini adalah kemampuan mengenali huruf dan menuangkannya baik dalam tulisan maupun suara melalui kegiatan menulis dan membaca. Kesimpulan penelitian ini adalah bahwa baik anak-anak maupun dewasa jika memiliki kemampuan dan kebiasaan membaca maka dapat memiliki kemampuan dalam memahami maksud dari ucapan yang diucapkan orang lain dibandingkan anak-anak dan orang dewasa yang memiliki tingkat kemampuan dan kemauan membaca rendah bahkan nihil. Selain itu, tingkat kemampuan membaca dapat mempengaruhi ketepatan maksud dari ucapan yang diutarakan oleh setiap individu (Huettig \& Pickering, 2019).

Melihat dari beberapa hasil penelitian terdahulu mengenai efek yang diberikan kepada individu melalui pengembangan pembiasaan berliterasi, menyebabkan munculnya ide pengadaan kegiatan pembinaan literasi yang didukung dengan sarana dan prasarana seperti perpustakaan, bahan bacaan, dan pelayanan peminjaman buku di Lapas Kelas IIB Tuban.

\section{Implementasi Pembinaan Literasi Terhadap Narapidana}

Lembaga pemasyarakatan merupakan lembaga pemerintah yang memiliki peranan sebagai wadah bagi pelaku tindak pidana. Ketika individu dinyatakan sebagai pelaku tindak pidana, tentu individu tersebut telah melakukan perbuatan yang menyimpang atau melanggar norma, peraturan, dan hukum yang berlaku, mulai dari hukum yang dibentuk oleh masyarakat sendiri hingga hukum resmi yang disahkan oleh negara. Munculnya penyimpangan terhadap individu mengartikan adanya gangguan sikap dan tingkah laku dari individu tersebut, karena sejatinya norma dan hukum yang ditegakkan di masyarakat berfungsi untuk mengontrol dan membatasi perilaku seseorang agar tetap sesuai dengan fitrahnya. Penyimpangan perilaku yang terjadi pada individu juga disebabkan karena kurangnya pemahaman masing-masing individu terhadap setiap informasi yang diterima sehingga tidak menghasilkan kesimpulan informasi secara tepat yang selanjutnya menentukan bagaimana seseorang bersikap. Oleh karena itu, secara tidak langsung lembaga pemasayarakatan yang merupakan wadah pelaku tindak pidana memiliki tanggung jawab untuk memperbaiki sikap dan tingkah laku yang melekat pada narapidana sesuai dengan fungsi pemasyarakatan yang dinyatakan pada salah satu pasal dalam UU Nomor 12 Tahun 1995 tentang pemasyarakatan. 
Sebagai upaya pelaksanaan fungsi pemasyarakatan, pemerintah juga mengungkapkan upaya yang dapat dilakukan yakni melalui pembinaan salah satunya adalah dengan diadakannya pembinaan literasi yang berfokus pada peningkatan kemampuan pemahaman narapidana sehingga dapat mempengaruhi sikap dan tingkah laku narapidana sehingga dapat pula kembali ke dalam masayarakat dengan kondisi yang kondusif. Berdasarkan hasil wawancara dengan informan pada tanggal 21 April 2021 dengan tempat dan jam yang berbeda, diperoleh informasi bahwa program pembinaan literasi dilaksanakan dengan tujuan untuk memperbaiki sikap dan tingkah laku narapidana, serta untuk mengisi waktu luang yang dimiliki oleh setiap narapidana ketika menjalani masa pidananya di dalam penjara. Berikut beberapa jawaban hasil wawancara antara penulis dengan informan:

Informan 1 : "Program pembinaan disini dilaksanakan dengan tujuan agar narapidana dapat berubah menjadi lebih baik, lebih santun, dan juga mengisi waktu luangnya karena terkadang ada narapidana itu yang suka melamun saja ketika tidak ada kegiatan."

Untuk mengadakan program pembinaan literasi tentunya dibutuhkan fasilitas, sarana, dan prasarana yang dapat mendukung sehingga dapat berjalan optimal. Lapas Kelas IIB Tuban telah mengadakan ruangan yang digunakan sebagai perpustakaan atau tempat penyimpanan bahan bacaan yang ada di lapas. Bahan bacaan yang digunakan sebagai alat pendukung pelaksanaan pembinaan diperoleh dari berbagai sumber mulai dari pihak lapas sendiri hingga pihak luar. Penyediaan bahan bacaan yang berasal dari lapas merupakan hasil sumbangan oleh petugas pemasyarakatan itu sendiri. Selain itu, lapas juga mengalokasikan anggaran pembinaan dalam hal penyediaan sarpras pembinaan untuk membeli bahan bacaan. Sebagai upaya menambah bahan bacaan, Lapas Kelas IIB Tuban menjalin hubungan kerja sama dengan pihak ketiga yang terdiri dari perpustakaan daerah kabupaten dan Universitas Sunan Bonang yang merupakan universitas swasta yang ada di Tuban. Kerja sama yang terjalin dengan Universitas Sunan Bonang tersebut yakni dengan penerimaan sumbangan bahan bacaan dari mahasiswa untuk lapas dan sumbangas dari pihak universitas itu sendiri. Sedangkan pola kerja sama yang terjalin dengan perpustakaan daerah adalah dengan diberikan pinjaman sejumlah buku oleh perpustakaan kepada lapas. Buku-buku tersebut akan diganti dengan buku lain oleh pihak perpustakaan daerah dalam kurun waktu tertentu.

Pengadaan bahan bacaan bagi narapidana harus melewati seleksi terlebih dahulu. Seperti yang diinformasikan oleh informan 2, bahwa setiap bahan bacaan yang masuk ke dalam perpustakaan lapas harus melalui tahap seleksi oleh petugas yang bertugas sebagai pendamping pembinaan literasi dan yang menjaga perpustakaan. Bahan bacaan yang patut diberikan kepada narapidana adalah bahan bacaan yang dapat memotivasi narapidana ke arah yang lebih positif. Bahan bacaan yang cenderung memiliki paham "garis keras" tidak akan diterima oleh lapas dan akan dikembalikan kepada pihak yang memfasilitasi.

Pelaksanaan pembinaan literasi tidak selalu berada di dalam ruangan perpustakaan. Hal ini tidak lain adalah karena luas area ruangan perpustakaan yang ada cukup kecil dan tidak dapat menampung setiap narapidana yang hendak melaksanakan program. Melihat cukup banyak narapidana yang tertarik mengikuti program pembinaan literasi ini, akhirnya lapas menyediakan layanan peminjaman buku sehingga setiap narapidana memiliki kesempatan lebih besar untuk mengikuti program pembinaan ini. Proses peminjaman buku dinilai juga sebagai absensi narapidana dalam melakukan pembinaan melalui absensi menggunakan alat fingerprint yang hasilnya akan terekam di dalam komputer. Rekaman absensi ini berfungsi sebagai alat bukti pendukung bagi narapidana ketika hendak mengajukan program integrasi dan asimilasi.

Dalam setiap pelaksanaan pembinaan baik kepribadian maupun kemandirian tentu memiliki masing-masing standar ukuran berhasilnya pembinaan terhadap narapidana. Dalam konteks penelitian kali ini, ukuran berhasilnya pembinaan literasi adalah 
meningkatnya pemahaman narapidana ketika menerima informasi yang diperoleh baik melalui media massa maupun dari komunikasi antar sesama narapidana bahkan dengan petugas. Meningkatnya pemahaman ini secara tidak langsung juga mengembangkan pola pikir narapidana sehingga dapat berpikir secara kritis dan rasional dalam jangka waktu panjang yang berpengaruh pula terhadap keputusan yang akan diambil dalam kehidupannya (Walgermo et al., 2018). Selain itu, pembinaan literasi dianggap berhasil juga ketika narapidana mengalami perubahan dari karakter, sikap, dan tingkah laku ke arah yang lebih positif. Berikut penggalan wawancara yang menunjukkan terjadinya perubahan sikap dan tingkah laku pada narapidana.

Informan 1 : "Banyak perubahan tampak dari narapidana yang mengikuti program pembinaan, yang awalnya saat masuk dan belum mengikuti program dan setelah mengikuti program pembinaan. Bentuk perubahannya menyebabkan kondisi interaksi antar narapidana menjadi kondusif dengan terjalinnya komunikasi yang baik antar narapidana sehingga mengurangi kesalahpahaman yang dapat berdampak pada keamanan lapas."

Informan 2 : "Ada banyak perubahan. Contohnya, dulu mereka kalau ada kegiatan malasmalasan dan ketika ada petugas, mereka tidak pernah nyapa. Namun setelah menjalani program pembinaan mereka jadi lebih sopan santun. Selain itu, muncul juga interaksi yang positif antar narapidana. Ketika program pembinaan literasi berlangsung, narapidana yang lebih handal dalam membaca dan menulis terkadang mengajari narapidana lain yang belum terlalu pandai membaca dan menulis."

Hal ini juga didukung oleh informan 3 dan informan 4 yang merupakan narapidana di Lapas Kelas IIB Tuban.

Informan 3 : "Dari program pembinaan yang ada di sini, saya jadi bisa mengetahui mana yang baik dan mana yang buruk. Saya juga lebih bisa mengontrol emosi saya ketika menghadapi masalah."

Informan 4 : "Banyak yang saya rasakan, biasanya kan banyak yang salah paham, sedangkan di sini rata-rata orangnya memiliki watak yang keras. Dari pembinaan literasi itu jadi bisa lebih memahami orang-orang yang masuk ke dalam sini melalui komunikasi yang baik yang disesuaikan dengan watak masing-masing narapidana."

Petugas Pemasyarakatan menjadi sosok yang terjun secara langsung dalam upaya pencapaian tujuan pemasyarakatan melalui kegiatan pembinaan. Kegiatan pembinaan harus mendapat pengawasan atau didampingi oleh petugas dengan tujuan agar ketika narapidana kurang memahami kegiatan pembinaan secara detail dapat mengajukan pertanyaan kepada petugas sehingga dapat melaksanakan pembinaan dengan sesuai. Tidak hanya itu, pengawasan dan pendampingan yang dilakukan oleh petugas berfungsi untuk mengamati setiap kegiatan narapidana sehingga dapat mengantisipasi aktivitas yang melanggar tata tertib lapas. Hasil pengamatan ini dapat berfungsi sebagai statement pendukung untuk mendapat program integrasi dan asimilasi ketika sidang TPP. Meskipun telah dilakukan pengawasan dan pendampingan terhadap narapidana, masih ada saja narapidana yang tidak mau mengikuti pembinaan yang disediakan oleh lapas. Mengatasi problematika ini, petugas terkadang mengalami dilema karena tetap harus menegakkan HAM ketika berhadapan dengan narapidana yang bebal dan sulit diatur. Seperti yang kita ketahui, bahwa pemasyarakatan dalam menghadapi narapidana juga berlandaskan pada Standard Minimum Rules atau yang lebih dikenal sebagai Mandela Rules yang tentunya selalu mengedepankan Hak Asasi Manusia dari setiap individu narapidana. 
Dalam upaya pelaksanaan pembinaan literasi, petugas dan lapas khususnya Lapas

Kelas IIB Tuban mengalami beberapa kendala sebagai berikut:

1. Ruangan perpustakaan yang kurang memadai

Dengan luas area perpustakaan yang kurang memadai lapas melakukan bentuk inovasi berupa layanan peminjaman buku oleh narapidana. Namun hal ini juga menciptakan masalah baru. Berdasarkan pernyataan wawancara dari informan 2, terkadang narapidana yang meminjam bahan bacaan tidak mengembalikan bahan bacaan tersebut ke perpustakaan. Karena diperolehkan untuk dibawa masuk ke kamar narapidana, terkadang ketika narapidana telah selesai menjalani masa pidana dan kembali pulang, bahan bacaan tersebut terbawa sehingga mengurangi jumlah buku yang ada dan mempengaruhi terlaksananya pembinaan literasi secara optimal.

2. Kurangnya jumlah petugas pendamping

Jumlah narapidana di Lapas Kelas IIB Tuban per tanggal 5 April 2021 adalah 222 orang dengan jumlah kotor petugas yakni 65 orang yang mana hanya 3 orang petugas yang bertugas di bagian pembinaan. Melihat perbandingan jumlah yang tidak seimbang ini membuat pengawasan dan pendampingan tidak dapat berjalan dengan maksimal. Meskipun kondisi narapidana di dalam lapas termasuk kondusif, tentu tetap dibutukan strategi antisipatif terhadap keamanan lingkungan di lapas untuk menjaga kekondusifan keadaan lingkungan lapas.

3. Masih ada narapidana yang sulit untuk ikut berkontribusi dalam melakukan pembinaan literasi

Adanya narapidana yang sulit untuk berkontribusi dalam melakukan pembinaan terutama pembinaan literasi sudah sering terjadi di berbagai unit pelaksana teknis pemasyarakatan lainnya. Hal ini bukan tanpa dasar, karena narapidana yang berada di dalam lapas tentu memiliki karakter yang berbeda-beda dan memiliki keistimewaan tersendiri sehingga timbul problematika tersebut. Untuk mengatasi hal tersebut ada berbagai macam cara yang dapat dilakukan oleh petugas pemasyarakatan dengan tetap memperhatikan HAM dari setiap narapidana.

\section{PENUTUP}

Pembinaan literasi diselenggarakan untuk menciptakan perubahan yang positif pada sikap dan tingkah laku narapidana. Upaya perubahan tersebut dilakukan melalui pengembangan pola pikir narapidana dengan cara melakukan kegiatan membca sekaligus memahami isi dari bahan bacaan ataupun informasi yang didapat baik melalui tulisan maupun lisan. Program pembinaan yang diselenggarakan oleh Lapas Kelas IIB Tuban telah menunjukkan hasil melalui perubahan sikap dan tingkah laku narapidana ke arah yang lebih baik. Emosi yang menggebu-nggebu menjadi lebih terkontrol setelah narapidana mengikuti program pembinaan literasi ini sehingga dapat menjaga kekondusifan lingkungan di dalam lapas. Namun, meskipun pembinaan ini cukup diminati oleh narapidana, masih ada narapidana lain yang terkadang antara niat dan tidak niat ketika mengikuti pembinaan ini. Selain itu, fasilitas pendukung yang kurang tersedia menjadi salah satu masalah paling mendasar karena hal tersebut membuat jumlah bahan bacaan berkurang akibat tidak dikembalikannya bahan bacaan tersebut ketika disediakan layanan peminjaman. Selain itu, pengawasan yang harus dilakukan oleh petugas menjadi lebih luas dan tidak dapat fokus di satu tempat saja dengan pertimbangan jumlah petugas yang terlalu sedikit.

\section{Saran}

Berdasarkan hasil penelitian dan kesimpulan di atas, penulis memiliki saran sebagai berikut:

1. Pengembangan program pembinaan literasi melalui inovasi-inovasi baru perlu dilakukan seiring dengan kemajuan zaman sehingga narapidana yang berada di dalam penjara tidak tertinggal oleh kemampuan masyarakat yang berada di luar tembok penjara dalam menghadapi kemajuan zaman. 
2. Melengkapi dan memperbaiki fasilitas, sarana dan prasarana pendukung pelaksanaan pembinaan literasi sehingga dapat mengurangi masalah-masalah lain yang muncul akibat dari sarpras yang kurang memadai. Dengan adanya perbaikan fasilitas dan sarpras secara tidak langsung dapat menarik minat berliterasi dari masing-maisng narapidana yang ada di lapas.

3. Menambah jumlah pihak ketiga yang akan diajak untuk menjalin kerja sama dalam upaya mendukung kegiatan literasi narapidana. Selain bahan bacaan, lapas juga dapat mencoba menjalin kerja sama dengan tenaga pendidik yang memiliki kompetensi dalam melakukan pengajaran baca dan tulis, serta pemahaman informasi. Hal ini dapat menjadi salah satu jalan keluar yang cepat dalam mengatasi problematika kurangnya tenaga pendamping dan pengawas dari petugas pemasyarakatan.

Dalam menghadapi narapidana yang memiliki beragam karakteristik, dengan tetap menegakkan HAM, petugas dapat melakukan upaya pendekatan, motivasi, dan pemberian pengertian melalui sosialisasi mengenai fungsi dan manfaat yang didapatkan ketika mengikuti program pembinaan yang disediakan.

\section{DAFTAR PUSTAKA}

\section{Peraturan Perundang-Undangan}

Peraturan Pemerintah No.31 Tentang Pembinaan dan Pembimbingan Warga Binaan Pemasyarakatan, (1999)

UU No. 12 Tahun 1995 Tentang Pemasyarakatan, (1995). www.bphn.go.id

\section{Buku}

Purwoko, Y. (2001). Memecahkan Masalah Remaja. Nuansa

\section{Artikel Jurnal}

Akbar, A. (2017). ISSN 2540-9093 MEMBUDAYAKAN LITERASI DENGAN PROGRAM 6M DI SEKOLAH DASAR Aulia Akbar Program Studi PGSD STKIP sebelas April Sumedang A . Pendahuluan Indonesia merupakan negara maupun masyarakat peduli akan yang kaya akan sumberdaya alam, namun potensi ini. Pendidikan Sekolah Dasar, $3(1), 42-52$.

Anggraeni, H., Fauziyah, Y., \& Fahyuni, E. F. (2019). Penguatan Blended Learning Berbasis Literasi Digital Dalam Menghadapi Era Revolusi Industri 4.0. Al-Idarah: Jurnal Kependidikan Islam, 9(2), 190-203. http://ejournal.radenintan.ac.id/index.php/idarohe-ISSN:25802453https://doi.org/10.24042/alidarah.v9i2.5168

Bella, K. O., Indriyani, M., \& Fajar, C. (2019). Peran Perpustakaan Lembaga Pemasyarakatan Klas I Malang dalam meningkatkan literasi informasi narapidana. 7(1), 49-64.

Dwiatmodjo, H. (2013). PELAKSANAAN PIDANA DAN PEMBINAAN NARAPIDANA TINDAK PIDANA NARKOTIKA (Studi terhadap Pembinaan Narapidana di Lembaga Pemasyarakatan Narkotika Klas IIA Yogyakarta). Perspektif, 18(2), 64. https://doi.org/10.30742/perspektif.v18i2.115

Hamja. (2014). Model Pembinaan Narapidana Berbasis Masyarakat ( Community Based Corrections ) Dalam Sistem Peradilan. 445-458.

Huettig, F., \& Pickering, M. J. (2019). Literacy Advantages Beyond Reading: Prediction of Spoken Language. Trends in Cognitive Sciences, 23(6), 464-475. https://doi.org/10.1016/j.tics.2019.03.008

Ridwan, M. (2016). Implementasi Pembinaan Kepribadian di Lembaga Pemasyarakatan. 
Jurnal Penelitian Hukum De Jure, 16(3), 323-336.

Walgermo, B. R., Frijters, J. C., \& Judith, O. (2018). Early Childhood Research Quarterly Literacy interest and reader self-concept when formal reading instruction begins. Early Childhood Research Quarterly, 44, 90-100. https://doi.org/10.1016/j.ecresq.2018.03.002

\section{Website}

[BPS] Badan Pusat Statistik. (n.d.). Berita resmi statistik. In Bps.Go.Id.

APJII. (2020). Jumlah Pengguna Internet di Indonesia Capai 196,7 Juta. Databoks.Katadata.Co.Id. https://databoks.katadata.co.id/datapublish/2020/11/11/jumlah-penggunainternet-di-indonesia-capai-1967-juta

KBBI, K. (2016). KBBI. Kbbi.Kemdikbud.Go.Id. https://kbbi.kemdikbud.go.id/entri/literasi 
